\title{
An Evaluation Of Italian Banks In The Period Of Financial Distress
}

Mitja Stefancic, University of Ljubljana, Slovenia

Neophytos Kathitziotis, University of Hamburg, Germany

\begin{abstract}
This paper evaluates the performance of Italian banks during the 2006-2009 period. Banks are analysed according to their business models and their main activities. The analysis focuses on both cooperative and commercial banks. By contrast to commercial banks, Italian cooperative banks do not perceive profit-making as a principle itself. These banks have been able to accumulate capital and provide credit to customers despite the ongoing crisis. On average, they manage their loan portfolio better than commercial banks. Findings suggest that cooperative banking in Italy should be encouraged due to its positive contribution to economic development and possibly financial stability.
\end{abstract}

Keywords: Italian Banks; Cooperative and Commercial Banks; Profitability in Banking; Financial Distress

\section{INTRODUCTION}

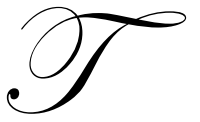

he aim of this paper is to analyse the recent performance of Italian banks, particularly during the 2007-2008 financial crisis. It therefore focuses on a topic that has been central to scholarly investigation in the past few years. Different types of financial intermediaries are evaluated according to the influence of profit-seeking on their business strategies. Specifically, the paper centres on two groups of banks - on the one hand, commercial banks; namely, privately owned banks that provide services both to the general public and to private firms - on the other hand, cooperative banks; namely, those with a "per capita" voting mechanism that provide services mainly to cooperative members, households, and small and medium-sized enterprises (SMEs).

A number of studies have shown that Italian cooperative banks and European cooperative banks are, on average, less profitable, yet more stable due to both higher solvency ratios (Hesse and Cihak, 2007; Gutierrez, 2008) and a number of advantages resulting from relationship banking such as a proximity to customers (Boot, 1999; Boot and Thakor, 2000; Cesarini, 2003; Di Salvo et al., 2004). A sound banking system is built primarily upon profitable and well-capitalised banks. This paper attempts to evaluate whether such an argument applies to the Italian market. Furthermore, the argument that a well-developed cooperative credit network increases the stability of the Italian financial system is indirectly discussed.

In principle, commercial banks are profit-driven. They tend to assume large risks. By contrast, cooperative banks tend to adopt conservative business strategies and stakeholder maximisation policies. Cooperative banks are customer-oriented and are particularly efficient in maintaining long-lasting relationships with their members and customers. Members at cooperative banks tend to enjoy easier access to credit. Stated otherwise, these banks are particularly strong in relationship banking, a type of banking which enables banks to make informed decisions in the provision of loans and financial services as a result of in-depth knowledge of customers' business (Baas and Schrooten, 2005a). In their loans-granting process, they are able to use "soft information" to substantiate their decisions (Berger and Udell, 2002; Petersen, 2002).

By evaluating different types of banks operating in the Italian market, an attempt is made to outline policy implications for the stability of the national financial system. Stability is defined both as a situation in which financial markets fulfil their allocation function in a satisfactory manner and as the stability of key institutions 
(Würz, 2005). The need to discuss such a topic is derived, for instance, from the argument that in any banking activity, there is a relationship between profitability and liquidity with important implications for financial stability. Banks manage profitability by trying to beat market averages and keep profits steady and predictable (Van Groening and Brajovic-Bratanovic, 2000; Valla et al., 2006). These issues need to be re-discussed in the aftermath of the 20072008 financial crisis.

Findings suggest that major differences exist in the business models of cooperative and commercial banks. Arguably, they originate from individual features of banks, their strategic goals, technical profile and organisational structure. Italian cooperative banks are efficient in providing credit to their customers despite the ongoing crisis. They have good management of the loan portfolio, which is qualitatively better than that of commercial banks. Results further suggest that the presence of cooperative credit banks translates into positive outcomes in terms of financial stability: diversification of financial institutions within the market provides a better balance of shareholder and stakeholder values. This, in turn, may positively affect financial stability.

\section{COOPERATIVE BANKS IN THE ITALIAN MARKET}

As Angelini and Cetorelli (2003) observe, Italy is one of the most important European economies. The Italian banking system has undergone a process of restructuring and significant consolidation in the 1990s. Developments have been multifaceted and had influenced different groups of banks and several financial intermediaries. Competition has increased as a result of the financial integration at the EU level. While cooperative banks had consolidated their position in local markets, commercial banks and some larger popular banks privileged growth strategies on a national level or in the European markets. As a result of the above-mentioned changes, commercial and cooperative banks play an even more important role for the Italian financial system.

In Italy, cooperative credit banks relate into a well-developed commercial network with important historical roots and market advantages (Angelini and Cetorelli, 2003; Finocchiaro, 2007; Leonardi, 2009). In order to better appraise such a network, it is important to note that European cooperative banking has a long-standing tradition dating back to the first half of the $19^{\text {th }}$ century. It gradually emerged as a response to the market inefficiencies and imperfections resulting from the financial activity of commercial banks at that time. Whereas savings banks flourished from 1810 onwards to overcome opportunistic behaviour by banks, cooperative banks flourished from the mid- $19^{\text {th }}$ century onwards to overcome opportunistic behaviour by borrowers (Hansmann, 1996; Fonteyne, 2007).

As in other European countries, Italian cooperative banks managed to overcome such inefficiencies because of the fact that members and consumers from local communities financed their own development and were directly involved in decision-making processes. As noted by Fonteyne, "within small communities, relatively intimate knowledge of each other's credit and trustworthiness ensured that loans were only provided to borrowers who could be expected to repay them. The financial incentives members had to monitor each other and the relatively small and homogeneous base of early cooperatives ensured that peer pressure provided incentives for borrowers to repay" (Fonteyne, 2007, 9).

Despite a changing environment and increasing market competition, many Italian cooperative banks still retain some of their original traits. Trust is an important concept in banking theory and remains a central value in cooperative banking as it developed in several Italian regions. Why it is important to stress the concept of trust and cooperative values in contemporary banking? Groeneveld and de Vries $(2009,11)$ provide a good answer to this question by looking at the aftermath of the financial crisis and potential developments in financial intermediation. They assert that "in the global financial system, integrity and ethics will play a more important role at financial institutions than in the past. Traditionally, the financial sector thrives on trust. At the same time, we expect the strong focus on short-term gains and materialism".

\section{Profitability in Cooperative Banking}

Profit-making is essential for banks to operate in the long-term. Banks play a major role in channelling funds for productive purposes. Therefore, they provide a fundamental contribution to economic development. Profit is also a major driver of the developments and the implementation of new financial services and products in the 
Italian banking sector:

- On the one hand, Italian banks differ with respect to the assumed importance of both short- and long-term profit maximisation.

- $\quad$ On the other hand, they differ in terms of profit allocation policies, which involve a number of risks; for example, operational risks, business risks, credit risk, liquidity risk, interest rate risk, as well as those related to their financial structure (Van Greuning and Brajovic-Bratanovic, 2000; Matthews and Thompson, 2008).

One can safely assume that such differences have an impact on the market structure of the banking sector.

Despite adopting a rather broad definition of "cooperative banks", results from several empirical studies show that Italian cooperative banks are more cost-efficient than their competitors (Girardone et al., 2004; Turati, 2004). It can be argued that commercial banks tend to pursue strategies aimed at short-term profit maximisation. Conversely, by registering large amounts of their annual earnings as reserves, cooperative banks tend to apply safer business strategies. As most other non-financial cooperatives, they apply an organisational model based on a governance in which the control of rights is exercised democratically and membership is voluntary.

By reference to Groeneveld and Sjauw-Koen-Fa (2009), it can be observed that the business model of Italian cooperative banks shows a number of specifics; for example, 1) corporate governance based on member ownership, 2) conservative business strategy, 3) high level of capitalisation, and 4) focus on retail banking. Despite not perceiving profit as a goal itself, they need to implement effective strategies to ensure profitability and offset the above-mentioned risks - "robust profit growth is also important for cooperative banks to safeguard their continuity and continuing development. Healthy profitability is a prerequisite, but not a goal itself. This means that cooperative banks can, in challenging times, including the present credit crisis, stay behind the customers longer than their listed rivals" (Groeneveld and de Vries, 2009, 11).

Table 1 summarises the specifics in terms of organisational structure, governance and business of, on the one hand, Italian cooperative banks; and, on the other hand, commercial banks.

Table 1: Organizational Differences between Italian Cooperative and Commercial Banks

\begin{tabular}{|l|l|l|}
\hline & \multicolumn{1}{|c|}{ Cooperative Banks } & \multicolumn{1}{c|}{ Commercial Banks } \\
\hline Corporate governance & Member ownership & Shareholder ownership \\
\hline Business strategy & OTH (originate to hold) & OTD (originate to distribute) \\
\hline Profitability & Consumer surplus maximisation & Short-term profit maximisation \\
\hline Line of business & Relationship banking and retail segment & Diversified \\
\hline Legal reserves & $70 \%$ of net profits retained as reserves & $10 \%$ of net profits retained as reserves \\
\hline Status & Do not issue equity & Issue equity and tradable shares \\
\hline
\end{tabular}

Source: the authors

\section{METHODOLOGY AND DATA}

The following question is crucial to the present study: "What is the best indicator for measuring profitability?" The answer depends on which part of the balance sheet one refers to. There are different measures and ratios that account for profitability in financial intermediation. This paper focuses on the return on equity (ROE); namely, the ratio that is commonly used by banks as the "ultimate performance scorecard". While some scholars and policymakers view this ratio as the most reliable indicator of profitability, others have criticised its extensive use (Karr, 2005; Tumpel-Gugerell, 2005; De Bonis, 2008, 114-116). Regardless of which position one subscribes to, ROE is a standard ratio. As such, it is a valuable tool for the analysis of both local banks and large international banks. This ratio is suitable for making a comparison between different types of banks. Needless to say, as with other analytical tools and methods, it needs to be used with judgment and caution. 
In the present paper, a model is developed in which ROE relates to a number of independent variables. Such a model enables to identify the sources and the structure of profitability among cooperative and commercial banks. In the following paragraphs, data sources and the sample of banks are discussed. A number of papers have been considered for deriving the model. The paper that mostly supported the final selection of independent variables is a study developed by Angela Romagnoli (2007) in which a set of variables is defined so to measure the profitability of Italian banks and asset returns on listed shares.

In order to derive the model, some of the original variables to measure the profitability of commercial banks have been omitted so as to better appraise the specifics of cooperative banks. For instance, Dividend-Payouts have been omitted due to the fact that they play a minor role in cooperative credit banking - cooperative banks "often face binding restrictions on their pay-out policies. At many cooperatives, there are statutory or legal restrictions that put limits on shareholder remuneration" (Fonteyne, 2007, 43). Furthermore, instead of using the Interbank Rate as a measure of liquidity for Italian cooperative banks, Liquid Assets over Total Assets are used as a standard measure of liquidity since cooperative banks do not engage in the interbank market as actively as commercial banks. The final variables are described in Table 2.

Table 2: Description of Variables used in the Model

\begin{tabular}{|c|c|c|c|}
\hline Measure Of & Variable & Short & $\begin{array}{l}\text { Definition } \\
\end{array}$ \\
\hline \multirow{3}{*}{ Asset Quality } & Total Capital Ratio & TCR & $\begin{array}{l}\text { Total capital adequacy ratio under the } \\
\text { Basle rules. It measures Tier } 1+\text { Tier } 2 \\
\text { capital }\end{array}$ \\
\hline & Net Loans on Total Assets & NLTA & $\begin{array}{l}\text { Indicates the percentage of the assets of } \\
\text { the bank tied up in loans }\end{array}$ \\
\hline & Net Loans on Deposits & NLTDB & $\begin{array}{l}\text { A ratio with deposits and borrowings as } \\
\text { its denominator (for the exception of } \\
\text { capital instruments) }\end{array}$ \\
\hline \multirow[b]{2}{*}{ Quality Of Investment } & Loan Loss Reserves on Gross Loans & LLRGL & $\begin{array}{l}\text { It is a reserve for losses expressed as a } \\
\text { percentage of total loans }\end{array}$ \\
\hline & $\begin{array}{l}\text { Loan Loss Provisions on Net } \\
\text { Interest Revenue }\end{array}$ & LLPNIR & $\begin{array}{l}\text { Defines the relationship between } \\
\text { provisions in the profit and loss account } \\
\text { and the interest income over a given } \\
\text { period }\end{array}$ \\
\hline \multirow{5}{*}{ Profitability } & Net Interest Margin & NIM & $\begin{array}{l}\text { The net interest income expressed as a } \\
\text { percentage of earning assets }\end{array}$ \\
\hline & $\begin{array}{l}\text { Non Operative Items \& Tax on } \\
\text { Average Assets }\end{array}$ & NOITAA & $\begin{array}{l}\text { A measure of costs and tax as a } \\
\text { percentage of assets }\end{array}$ \\
\hline & Return on Equity & ROE & $\begin{array}{l}\text { A standard measure of the return on } \\
\text { shareholder funds }\end{array}$ \\
\hline & Cost-to-Income Ratio & CIR & $\begin{array}{l}\text { Defines changes in the cost/asset ratio } \\
\text { and in the interest margin }\end{array}$ \\
\hline & Recurring Earning Power & REP & $\begin{array}{l}\text { A measure of after tax profits adding } \\
\text { back provisions for bad debts as a } \\
\text { percentage of Total Assets }\end{array}$ \\
\hline Liquidity & Liquid Assets over Total Assets & LQVT & $\begin{array}{l}\text { Derived by dividing liquid assets by } \\
\text { total assets }\end{array}$ \\
\hline
\end{tabular}

Source: BankScope

\section{Data Sources}

The model is developed on balance sheet data from a sample of 60 cooperative banks and 60 commercial banks in Italy. Despite acknowledging that different levels of efficiency exist among banks operating in different Italian regions and geographic areas (Battaglia and Ricci, 2008), the analysis is developed at a national level. Data are obtained through the BankScope database provided by Bureau van Dyke. They refer to the 4 -years period 20062009. This is the period of severe financial distress and recession and the year just before the spread of the crisis. It thus provides a "worst case" scenario for the analysis of banking behaviour. Such argument is substantiated by the 
idea that the macroeconomic situation affects the performance of the interbank market and the banking system as a whole and, therefore, of single banks as well (Quagliariello, 2008; Bank of England, 2009; Freixas, 2009).

A major problem in the sample selection relates to the definition of cooperative banks. Some studies classify all banks with a "per capita" voting mechanism; for example, mutual and rural banks as cooperative banks (Battistin et al., 2006). Taken together, these banks account for approximately $30 \%$ of both loans and deposits in the Italian banking system. However, significant differences exist between such categories of banks. In the construction of the database, insights from Gutierrez (2008) have been taken into account. Following her classification, the present study centres on the "banche di credito cooperativo" only. Such a choice adds substance to the analysis and thereby helps avoid confusion in the interpretation of results. This may, in turn, better substantiate our tentative policy guidelines, as listed at the end of the paper.

A second methodological problem in the present study refers to the treatment of outliers and missing values in the dataset. A very small number of banks have been excluded from the data set due to a large number of missing values. Any other missing values or outliers were replaced by the mean of the respective variable where this method was applicable. For example, the Total Capital Ratio was not available for a very small number of banks. However, since the variation of this variable, over time, is relatively low, we could use the respective average sample values as a proxy.

\section{MULTIVARIATE MODEL AND STATISTICAL ANALYSIS}

\section{Descriptive Statistics and Analysis}

First, the summary statistics of our data set, as outlined in Table 3, is investigated. They provide the reader with some interesting insights on the differences between the business models of cooperative and commercial banks in Italy.

To begin with, variables measuring the financial performance of commercial banks are more volatile than those of cooperative banks, as it is shown by the standard deviation. Several hypotheses have been tested to clarify this point. An investigation has been conducted to evaluate whether bank size, income composition and product mix increase the volatility of earnings and other ratios within commercial banks. Ultimately, it can be argued that by contrast to commercial banks, Italian cooperative banks relate into a consolidated network - the cooperative credit network - with a better distribution of financial risks. They are more homogenous within the sample; they also engage in fewer and more stable business segments which secures stability in their performance metrics. This result involves significant policy implications that will be discussed later in detail. Further implications can be drawn from the fact that Italian cooperative banks are successful in the retail banking segment, as it is shown by the concentration of loans in their portfolios. In the 2006-2009 period, by contrast to commercial banks and despite the ongoing crisis, cooperative banks continued to provide credit liquidity to the market.

As far as the loan portfolio is concerned, the lower LLRGL ratio stresses the efficiency of cooperative banks in providing loans as well as their ability to implement better management of loan portfolios than commercial banks. This ratio is, on average, higher for commercial banks and with increasing values in the period under examination, particularly in the years 2007 and 2008. Management of the loan portfolio in commercial banks only improved in 2009. Results suggest that Italian cooperative banks tend to manage their loan portfolios better and are particularly effective in retail business. They therefore confirm the validity of similar studies, which show that in times of financial and economic distress, Italian cooperative banks have a better quality of the loan-granting process. They are also able to implement more efficient recovery processes (Matarocci and Gibilaro, 2008). 
Table 3: Sample Means for the Variables in the Data Set for the Different Time Periods (Standard Deviations in Parentheses)

\begin{tabular}{|c|c|c|c|c|c|c|c|c|}
\hline \multirow[t]{3}{*}{ Variable } & \multicolumn{2}{|c|}{2006} & \multirow{2}{*}{\multicolumn{2}{|c|}{$\begin{array}{c}2007 \\
\text { Sample }\end{array}$}} & \multirow{2}{*}{\multicolumn{2}{|c|}{$\begin{array}{c}2008 \\
\text { Sample }\end{array}$}} & \multicolumn{2}{|c|}{2009} \\
\hline & \multicolumn{2}{|c|}{ Sample } & & & & & \multicolumn{2}{|c|}{ Sample } \\
\hline & $\begin{array}{c}\text { Cooperative } \\
\text { Banks }\end{array}$ & $\begin{array}{c}\text { Commercial } \\
\text { Banks }\end{array}$ & $\begin{array}{c}\text { Cooperative } \\
\text { Banks }\end{array}$ & $\begin{array}{c}\text { Commercial } \\
\text { Banks }\end{array}$ & $\begin{array}{c}\text { Cooperative } \\
\text { Banks }\end{array}$ & $\begin{array}{c}\text { Commercial } \\
\text { Banks }\end{array}$ & $\begin{array}{c}\text { Cooperative } \\
\text { Banks }\end{array}$ & $\begin{array}{c}\text { Commercial } \\
\text { Banks }\end{array}$ \\
\hline \multirow[t]{2}{*}{$\mathrm{ROE}$} & 0,0848 & 0,0868 & 0,0957 & 0,0735 & 0,0708 & 0,0036 & 0,0386 & 0,0319 \\
\hline & $(0,0290)$ & $(0,1043)$ & $(0,0284)$ & $(0,1510)$ & $(0,0260)$ & $(0,2302)$ & $(0,0257)$ & $(0,1068)$ \\
\hline \multirow[t]{2}{*}{ CIR } & 64,678 & 66,662 & 60,709 & 64,775 & 64,056 & 75,571 & 68,506 & 72,537 \\
\hline & $(8,1993)$ & $(25,652)$ & $(7,4877)$ & $(21,371)$ & $(8,2980)$ & $(64,014)$ & $(9,6996)$ & $(55,273)$ \\
\hline \multirow[t]{2}{*}{ REP } & 0,0052 & 1,3274 & 0,0056 & 1,4431 & 0,0046 & 0,9527 & 0,0025 & 0,0009 \\
\hline & $(0,0072)$ & $(1,6397)$ & $(0,0077)$ & $(1,6734)$ & $(0,0071)$ & $(1,1759)$ & $(0,0037)$ & $(0,0020)$ \\
\hline \multirow[t]{2}{*}{ NIM } & 0,0132 & 0,0030 & 0,0121 & 0,0027 & 0,0113 & 0,0025 & 0,0071 & 0,0018 \\
\hline & $(0,0199)$ & $(0,0047)$ & $(0,0169)$ & $(0,0039)$ & $(0,0164)$ & $(0,0040)$ & $(0,0106)$ & $(0,0029)$ \\
\hline \multirow[t]{2}{*}{ NOITAA } & $-0,0010$ & 0,00008 & $-0,0009$ & $-0,0005$ & $-0,0006$ & $-0,0003$ & 0,0004 & $-0,0001$ \\
\hline & $(0,0015)$ & $(0,0023)$ & $(0,0016)$ & $(0,0011)$ & $(0,0011)$ & $(0,0007)$ & $(0,0063)$ & $(0,0010)$ \\
\hline \multirow[t]{2}{*}{ TCR } & 15,922 & 14,606 & 15,708 & 14,671 & 15,389 & 13,7090 & 14,778 & 14,982 \\
\hline & $(5,9400)$ & $(9,6775)$ & $(5,3535)$ & $(12,962)$ & $(4,7122)$ & $(8,7375)$ & $(3,3033)$ & $(9,7795)$ \\
\hline \multirow[t]{2}{*}{ NLTA } & 0,7081 & 0,9770 & 0,7362 & 0,9810 & 0,7401 & 1,4728 & 0,7401 & 0,6256 \\
\hline & $(0,1372)$ & $(3,0086)$ & $(0,1033)$ & $(2,8884)$ & $(0,1035)$ & $(6,8206)$ & $(0,1010)$ & $(0,2718)$ \\
\hline \multirow[t]{2}{*}{ NLTDB } & 1,3527 & 1,0540 & 1,4672 & 1,0886 & 1,5563 & 1,0895 & 1,5108 & 0,6256 \\
\hline & $(0,3720)$ & $(0,6474)$ & $(0,3577)$ & $(0,7237)$ & $(0,4011)$ & $(0,5568)$ & $(0,3800)$ & $(0,5351)$ \\
\hline \multirow[t]{2}{*}{ LLRGL } & 0,0176 & 13,028 & 0,0170 & 0,1006 & 0,0183 & 17,746 & 0,0189 & 0,0323 \\
\hline & $(0,0139)$ & $(105,78)$ & $(0,0140)$ & $(0,4842)$ & $(0,0121)$ & $(144,41)$ & $(0,0095)$ & $(0,0179)$ \\
\hline \multirow[t]{2}{*}{ LLPNIR } & 0,0816 & 0,1621 & 0,0984 & 0,2372 & 0,1468 & 0,4304 & 0,2101 & 0,3568 \\
\hline & $(0,0634)$ & $(0,2728)$ & $(0,0597)$ & $(0,6866)$ & $(0,0940)$ & $(1,4326)$ & $(0,1429)$ & $(0,3423)$ \\
\hline \multirow[t]{2}{*}{ LQVT } & 0,0904 & 4,1772 & 0,0932 & 3,0764 & 0,0838 & 0,2340 & 0,0782 & 0,2157 \\
\hline & $(0,0837)$ & $(32,666)$ & $(0,0818)$ & $(23,572)$ & $(0,0660)$ & $(0,2409)$ & $(0,0682)$ & $(0,2241)$ \\
\hline Observations 60 & 58 & 57 & 58 & 57 & 58 & 58 & 60 & 60 \\
\hline
\end{tabular}

Source: Own calculations based on data from BankScope 
On the other hand, the deterioration of the LLPNIR variable clearly shows that in the period under investigation, both groups of banks have been facing substantial risks from distressed borrowers. This would require banks to have higher capitalisation as a measure of dealing with unexpected losses. In fact, during the period in question, cooperative banks have managed to set aside enough capital as opposed to commercial banks. This result is confirmed by the higher total capital ratio held by cooperative banks, based on the Basel guidelines. Arguably, cooperative banks, on average, tend to pursue rather conservative policies which result in being socially efficient in times of distress due to their positive economic influence. The following interpretation helps shed light on the conservative management of capital and reserves - if excessive obligatory reserves and statutory capital requirements can damage profits in "normal" times, the ability to accumulate capital is particularly important in times of financial distress as bank capital prevents banks from becoming insolvent.

The REP ratio is mainly a measure of asset utilization. In this respect, it shows that, at first sight, commercial banks manage their overall assets portfolio better. This is determined both by the fact that this ratio adds up the provisions which are much higher in commercial banks and moreover, because the blend of assets in commercial banks is more aggressive than the typical loan - bonds portfolio of cooperative banks.

Further insights are obtained by taking the concept of liquidity into account. Liquidity is one of the key measures for both the overall bank performance and its contribution to the stability of financial markets. Following from Valla et al. (2006), the present analysis centres on the liquidity in individual banks or, in the case of cooperative banks, well-consolidated banking networks. As already noted, Italian cooperative banks have substantial loan portfolios which enable them to provide credit to customers and SMEs, in particular. However, under specific circumstances, concentration of loans in the asset side of the balance sheet could impair their ability to repay any commitments due. This situation is often referred to as the "maturity mismatch". Commercial banks have been tackling this problem in the past years with an increased use of interest-rate swaps, interbank loans and other instruments (Hesse and Cihak, 2007; Memmel and Schertler, 2009). The lack of access by cooperative banks to the interbank market and the lack of knowledge to use derivatives impairs their position in managing liquidity. One may argue that this aspect actually signals a lack of flexibility in the business model adopted by Italian cooperative banks.

Overall, the conservative business model of Italian cooperative banks appears to be rather successful in times of financial distress. Indeed, in the period under examination, ROE has been stable at around 8-9\%, whereas in the same period, commercial banks have suffered major losses resulting in lower levels of ROE. These results are not surprising, as in a similar study by Baas and Schrooten (2005b) which investigates the profitability of German banks during the 1994-2003 period, and shows that, on average, cooperative and popular banks have both more stable and higher profitability than commercial banks. It is interesting to observe that a rather different picture emerges in 2009 where ROE in both groups is lower than $4 \%$.

In the evaluation of different business models in commercial and cooperative banks, a major issue is that of efficiency. As mentioned earlier, empirical results related to this concept cannot be interpreted in a straightforward manner. They are open to interpretation. The CIR ratio shows that, on average, cooperative banks are run more efficiently than commercial banks. This might be due to the fact that commercial banks have experienced higher volatility in their trade portfolios during the crisis, thus producing lower income. These banks operate in a more competitive market segment where salaries - a major cost component in the balance sheet - tend to be higher. Table 4 summarises the differences in the business models of the two banking groups, as described in the current section.

Table 4: Business Model Blueprint during Financial Distress

\begin{tabular}{|l|l|l|}
\hline \multicolumn{1}{|c|}{ Indicators } & \multicolumn{1}{|c|}{ Cooperative Banks } & \multicolumn{1}{c|}{ Commercial Banks } \\
\hline Profitability & Stable & Volatile \\
\hline Typology of activity & Retail market & Diversified \\
\hline Credit business & Substantial loan portfolios & Decreasing lending activities \\
\hline Quality of investments & Both groups face risks & At regulatory levels \\
\hline Capital set aside & Conservative policy & Increasing costs \\
\hline Operational efficiency & Improved operational efficiency & Overall higher asset utilization \\
\hline Asset efficiency & Lower income generating asset mix &
\end{tabular}

Source: the authors 


\section{Model Specification and Estimation}

To examine the determinants of bank profitability, two models using pooled OLS and fixed effects (FE) regression have been estimated (results are shown in Table 5, at the end of this paragraph). The advantage of adopting panel analysis for this study stems from its ability to control individual (bank) heterogeneity and to detect relationships that are not observable in pure cross-section and time-series data through the dynamics of adjustment. The FE models were estimated using White's transformation in order to control for heteroskedasticity among the cross-sections. While investigating the relationship in question, a number of regressions to control for different variables pertinent to bank profitability have been employed. Subsequently, the model boiled down to the following equation:

ROE $=\beta_{1}+\beta_{2} *$ NIM $+\beta_{3} *$ TCR $+\beta_{4} *$ REP $+\beta_{5} *$ NLTA $+\beta_{6} *$ LQVT $+\beta_{7} *$ LLPNIR

where ROE stands for Return on Equity; NIM stands for Net Interest Margin; TCR stand for Total Capital Ratio; REP stands for Recurring Earning Power; NLTA stands for Net Loans on Total Assets; LQVT stands for Liquidity; and finally, LLPNIR stands for Loan Loss Provisions on Net Interest Revenue.

A first interpretation of results reveals a number of interesting insights concerning the profitability of banks. A summary of the results from the performed regressions is outlined in Table 2. To begin with, the model seems to reveal no relationship between the total capital ratio and profitability. This can be interpreted with reference to the fact that the required rate of this ratio is determined by the regulatory authorities and this does not leave place for the banks to manipulate it. However, in a more detailed research, case studies of banks at the extreme of the TCR values ought to be considered, as it is clear that one should expect some kind of a relationship between ROE and TCR. Based on the present data, one can conclude that regulatory capital does not have a significant influence on ROE.

Moving to the quality of investments, the LLPNIR estimate indicates that profitability in cooperative banks is negatively related to this variable, as one would normally expect. This estimate is relevant for both bank groups as, on average, their asset portfolios are structured with loans; thus, a small rise in the provisions for losses in loans indicates a decrease in profitability.

Table 5: Regression Results

\begin{tabular}{|l|c|c|c|c|}
\hline \multirow{2}{*}{ Variable } & \multicolumn{2}{|c|}{ Commercial Banks } & \multicolumn{2}{c|}{ Cooperative Banks } \\
\cline { 2 - 5 } & $\mathbf{O L S}$ & $\mathbf{F E}$ & $\mathbf{\text { OLS }}$ & $\mathbf{( 2 )}$ \\
\hline $\mathrm{C}$ & & $\mathbf{( 2 )}$ & & 0.112573 \\
\hline & & -0.037968 & & $(0.0000)$ \\
\hline TCR & $(0.0460)$ & -0.000158 & 0.002002 \\
\hline NIM & -0.002009 & -0.002077 & $(0.7050)$ & $(0.0021)^{* * *}$ \\
\hline & $(0.0263)^{* *}$ & $(0.0850)^{*}$ & -4.897328 & -7.853180 \\
\hline LQVT & -3.076747 & 14.64754 & $(0.0000)^{* * *}$ & $(0.0000)^{* * *}$ \\
\hline & $(0.0393)^{* *}$ & $(0.0135)^{* *}$ & 0.157686 & 0.080619 \\
\hline REP & 0.133432 & -0.000501 & $(0.0000)^{* * *}$ & $(0.0734)^{*}$ \\
\hline & $(0.0003)^{* * *}$ & $(0.0217)^{* *}$ & 12.77792 & 17.22024 \\
\hline NLTA & 0.030956 & 0.064015 & $(0.0000)^{* * *}$ & $(0.0000)^{* * *}$ \\
\hline & $(0.0000)^{* * *}$ & $(0.0000)^{* * *}$ & 0.121847 & -0.046711 \\
\hline LLPNIR & 0.089155 & -0.006743 & $(0.0000)^{* * *}$ & $(0.0484)^{* *}$ \\
\hline & $(0.0013)^{* *}$ & $(0.0000)$ & -0.189618 & -0.219295 \\
\hline Adj. R-squared & -0.080241 & 0.013761 & $(0.0000)^{* * *}$ & $(0.0000)^{* * *}$ \\
\hline
\end{tabular}

Note: p-values in parentheses; * significant at $10 \%$; ** significant at $5 \%$; *** significant at $1 \%$.

OLS = ordinary least squares estimate; $\mathrm{FE}=$ fixed effect estimate;

Source: the authors 
With REP being one of the most important indicators of asset utilization, it appears to be an important contributor for the ROE of both bank groups. Considering next the FE estimate of NLTA, results suggest that it is negatively related to profitability. Here one can conclude that when accounting for their individual effects, both banking groups in the data set tend to show some kind of a diminishing returns effect as their loan portfolio grows above a certain threshold.

\section{CONCLUSION}

This paper developed a model based on data from both commercial and cooperative banks in Italy to test for the profitability of banks. For such a model to be useful, it needs to address reality in its conclusions and appraise policy implications. With reference to the Italian market, results tend to confirm that major differences exist in the business models of cooperative and commercial banks. They originate from the individual features of banks, their strategic goals and business philosophies, technical profile, and organisational structure (Ferri, 2008; Groeneveld and de Vries, 2009; Tarantola, 2009; EACB, 2010). Also, Italian cooperative credit banks do not engage in the interbank market as actively as commercial banks and have therefore been less exposed to the financial crisis.

Such differences persist in times of financial distress. Italian cooperative banks show a remarkable efficiency in providing credit to their customers despite the ongoing crisis. Cooperative members, ordinary customers and SMEs continue to enjoy access to credit at cooperative banks. Results are thus consistent with the argument that relationship banking is particularly efficient in times of financial distress (Boot, 1999; Cesarini, 2003; Di Salvo et al, 2004; Ferri, 2008). They have a good management of loan portfolios which appears to be qualitatively better than that of commercial banks. A further advantage of cooperative banks is in their ability to accumulate capital in distressful times due to conservative business and development policies. This, in turn, lowers the risk of insolvency, thereby decreasing related problems such as potential bank-runs.

Despite pointing to a lack of flexibility in their business model, results confirm the positive economic contribution of Italian cooperative banks during the 2006-2009 period. Arguably, their presence in the Italian market translates into positive outcomes in terms of financial stability. Whereas diversification at financial institutions, for instance in the structure of the portfolio, may increase the likelihood of systemic crises (De Jonghe, 2010; Wagner, 2010), diversification of financial institutions within the market with a better balance of shareholder and stakeholder values can have positive effects on financial stability. Although the conclusion here is limited to the Italian market, it can be argued that similar results can be expected from research focusing on banks operating in other European countries. From the point of view of business development and market-making, it may be particularly fruitful to extend the cooperative credit network to countries where cooperative banking is either poorly developed or still missing; for instance, new EU member states such as Slovenia or other Central and Eastern European countries.

\section{ACKNOWLEDGEMENTS}

In completing the paper, we received valuable feedbacks from Professor Clara Graziano (University of Udine, Italy), Professor Aleksandra Gregorič (Copenhagen Business School, Denmark) and Angela Romagnoli (Bank of Italy). The usual disclaimer applies.

\section{AUTHOR INFORMATION}

Mitja Stefancic is a $\mathrm{PhD}$ candidate in "Economics and Business" at the Faculty of Economics, University of Ljubljana, Slovenia. He holds an MPhil in "Modern Society and Global Transformations" from the University of Cambridge. Before enrolling at the $\mathrm{PhD}$ programme, he has been employed for two years in a cooperative credit bank operating in the Friuli-Venezia Giulia region, Italy. Email: mitja.s@ hotmail.it

Neophytos Kathitziotis is a PhD candidate in "Economics" at the School of Business, Economics and Social Sciences, University of Hamburg, Germany. He holds a Masters in "International Business Administration" from the University of Hamburg and the State University of Economics and Finance, St Petersburg, Russia. Currently, he is employed by a commercial bank based in Frankfurt, Germany. E-mail: neophytos.kathitziotis@ gmail.com 


\section{REFERENCES}

1. Angelini, P. and N. Cetorelli (2003). The Effects of Regulatory Reform on Competition in the Banking Industry, Journal of Money, Credit and Banking, 35(5), 663-684.

2. Baas, T. and M. Schrooten (2005a). Relationship Banking and SMEs: A theoretical Analysis, German Institute of Economic Research, DIW-Discussion papers, 469.

3. Baas, T. and M. Schrooten (2005b). Theoretische analyse der Gewinnsituation Im Deutchen Bankensektor, German Institute of Economic Research, DIW-Discussionpapiers, 502.

4. $\quad$ Bank of England (2009). The Role of Macroprudential Policy, Discussion Paper November 2009.

5. Battaglia, F. and O. Ricci (2008). Divari regionali e performance delle banche locali: il caso delle BCC italiane, Cooperazione di Credito, September-December 2008, 305-329.

6. Battistin, E. et al. (2006). Connections or Performance: What Determines Turnover of Italian Bankers? Working Paper 05-06-eco, Università degli Studi di Udine.

7. Berger, A.N. and G.F. Udell (2002). Small Business Credit Availability and Relationship Lending: The Importance of Bank Organisational Structure, The Economic Journal, 112, 32-53.

8. Boot, A.W.A. (1999). Relationship Banking: What Do We Know? Journal of Financial Intermediation, 9 , 7-25.

9. Boot, A.W.A and A.V. Thakor (2000). Can Relationship Banking Survive Competition? Journal of Finance, 55(2), 679-713.

10. Cesarini F. (2003). Il rapporto banca-impresa, Impresa, risparmio e intermediazione finanziaria: aspetti economici e giuridici, October, Trieste.

11. De Bonis, R. (2008). La banca, Rome: Carocci.

12. De Jonghe, O. (2010). Back to basics in banking? A micro-analysis of banking system stability, Journal of Financial Intermediation, 19(3), 387-417.

13. Di Salvo, R. et al. (2004). L'evoluzione del relationship banking nei mercati creditizi locali: il ruolo delle Banche di Credito Cooperativo, Cooperazione al Credito, January-June 2004, 81-113.

14. EACB (2010). European Co-operative Banks in the Financial and Economic Turmoil: First Assessment, Brussels: EACB Secretariat.

15. Ferri, G. (2008). Why Cooperative Banks Are Particularly Important at a Time of Credit Crunch (Mimeo), Università degli Studi di Bari.

16. Finocchiaro, A. (2007). Il network delle banche di credito cooperativo, Studi Economici e Sociali, 3, 11-22.

17. Fonteyne, W. (2007). Cooperative Banks in Europe - Policy Issues, IMF Working Paper WP/07/159.

18. Freixas, X. (2009). Monetary Policy in a Systemic Crisis, Oxford Review of Economic Policy, 25(4), 630653.

19. Girardone, C. et al. (2004). Analysing the Determinants of Bank Efficiency: The Case of Italian Banks, Applied Economics, 36, 215-227.

20. Groeneveld, H. and B. de Vries (2009). European Banks: First Lessons of the Subprime Crisis, International Journal of Co-Operative Management, 4(2), 8-21.

21. Groeneveld, J.M. and A. Sjauw-Koen-Fa (2009). Cooperative Banks in the New Financial System, Rabobank Group Report for the Duisenberg Lecture, Annual Meeting of the IMF and World Bank, October, Istanbul.

22. Gutierrez, E. (2008). The Reform of Italian Cooperative banks: Discussion of Proposals, IMF Working Paper WP/08/84.

23. Hansmann, H. (1996), The Ownership of Enterprise, Cambridge, MA: Harvard University Press.

24. Hesse, H. and M. Cihak (2007). Cooperative Banks and Financial Stability, IMF Working Paper WP/07/2.

25. Karr, J. (2005). Performance Measure in Banking: Beyond ROE, Journal of Performance Management, 18(3), 56-70.

26. Leonardi, A. (2009). Il credito cooperativo nella débâcle del sistema bancario italiano, Rivista della Cooperazione, 2/2009, 152-172.

27. Mattarocci, G. and L. Gibilaro (2008). Characteristics of the Recovery Process for Small Financial Intermediaries: The Case of Italian Cooperative Banks, Proceedings of the Academy of Banking Studies, $8(2)$.

28. Matthews, K. and J. Thompson (2008). The Economics of Banking, Chichester: Wiley. 
29. Memmel, C. and A. Schertler (2009). The dependency of the banks' assets and liabilities: evidence from Germany, Bundesbank, Discussion Paper Series 2, Banking and Financial Studies No 14/2009.

30. Petersen, M.A. (2002). Information: Hard and Soft, Kellog School of Management Working Paper.

31. Quagliariello, M. (2008). Does Macroeconomy Affect Bank Stability? Journal of Banking Regulation, 9(2), 102-105.

32. Romagnoli, A. (2007). Indici di bilancio e rendimenti in Borsa: un'analisi per le banche italiane, Tema di Discussione della Banca d'Italia 648/Novembre 2007.

33. Tarantola, A.M. (2009). Le banche popolari nel confronto competitivo: vocazione territoriale e profili di governance, 27 February 2009, Taormina.

34. Tumper-Gugerell, G. (2005). Regulation, Competition and Integration in EU Banking: What Drives Performance? - Revisiting Freiburg, Faculty of Economics and Behavioural Sciences at the AlbertLudwigs University, October, Freiburg.

35. Turati, G. (2004). Are Co-operative Banks and Stock Banks Different Contracts? Empirical Evidence Using a Cost Function Approach, Quaderni del Dipartimento "G. Prato", 69, Università degli Studi di Torino.

36. Valla, N. et al. (2006). Bank Liquidity and Financial Stability, Banque de France Financial Stability Review N. 9.

37. Van Greuning, H. and S. Brajovic-Bratanovic (2000). Analysing Banking Risk: A Framework for Assessing Corporate Governance and Financial Risk Management, Washington: World Bank.

38. Wagner, W. (2010). Diversification at financial institutions and systemic crises, Journal of Financial Intermediation, 19(3), 373-386.

39. Würz, M. (2005). Comments on James Barth et al. Rethinking Banking Regulation, Achieving Financial Stability in Small Sophisticated Economies Conference, October, Ljubljana. 


\section{NOTES}

